\title{
IMPLEMENTASI MODEL PEMBELAJARAN DIRECT INSTRUCTION (DI) BERBANTUAN MEDIA AUDIOVISUALUNTUK MENINGKATKAN HASIL BELAJAR IPA PADA PESERTA DIDIK KELAS V SDN-1 LANGKAI PALANGKA RAYA \\ Implementation Of Direct Instruction Direct Instruction Model Using Audiovisual Media To Improve The Learning Outcomes Of Scientific Learning In Grade V Students At SDN-1 Langkai Palangka Raya
}

\author{
Oleh: Dedy Setyawan* dan Agung Riadin** \\ Email: agung_riadin@yahoo.com
}

\begin{abstract}
ABSTRAK
Penelitian ini bertujuan untuk mendeskripsikan aktivitas belajar dan meningkatkan hasil belajar IPA menggunakan model pembelajaran Direct Instruction (DI) berbantuan media Audio Visual. Metode penelitian yang digunakan adalah penelitian tindakan kelas (PTK). Subjek penelitian kelas $\mathrm{V}$ sebanyak 25 orang peserta didik. Teknik pengumpulan data menggunakan observasi dan tes. Analisis data didasarkan pada hasil siklus saat proses pembelajaran. Hasil penelitian menunjukan bahwa 1) Aktivitas belajar peserta didik menjadi baik dengan menggunakan model pembelajaran Direct Instraction (DI) berbantuan media Audio Visual dalam pembelajaran IPA pada peserta didik kelas V SDN-1 Langkai Palangka Raya, aktivitas guru pada siklus I rata-rata 2,3 kategori cukup baik dan siklus II rata-rata 3,5 kategori baik, sedangkan aktivitas peserta didik siklus I rata-rata 2,5 kategori cukup dan siklus II rata-rata 3,5 kategori baik. 2) Dengan menggunakan model pembelajaran Direct Instraction (DI) berbantuan media Audio Visual pada peserta didik kelas V SDN-1 Langkai Palangka Raya hasil belajar IPA meningkat dengan hasil analisis pada Pra tindakan ketuntasan klasikal yaitu 52\% dengan nilai rata-rata 65, siklus I ketuntasan klasikal yaitu 64\% dengan nilai ratarata 73, dan ketuntasan klasikal siklus II 92\% dengan nilai rata-rata 86.
\end{abstract}

Kata Kunci: Model Pembelajaran Direct Instruction (DI), Media Audio-Visual, Hasil Belajar IPA.

\begin{abstract}
This study aims to describe learning activities and improve science learning outcomes using the Direct Instruction (DI) learning model assisted by Audio Visual media. The research method used was graderoom action research (CAR). Grade V research subjects were 25 students. Data collection techniques using observation and tests. Data analysis is based on the results of the cycle during the learning process. The results showed that 1) Student learning activities became good by using Direct Instraction (DI) learning models assisted by Audio Visual media in natural science learning in grade V students of SDN-1 Langkai Palangkaraya, teacher activities in cycle I on average 2, 3 categories are good enough and the second cycle is on average 3.5 good categories, while the activities of the first cycle students average 2.5 categories enough and the second cycle an average of 3.5 good categories. 2) By using the Direct Instraction (DI) model assisted by Audio Visual media on grade V students of SDN-1 Langkai Palangka Raya, the science learning outcomes improved with the results of the analysis on gradeical completeness pre-action, namely $52 \%$ with an average value of 65 , cycle
\end{abstract}

*Dedy Setyawan dan **Agung Riadin

Dosen Fakultas Keguruan dan Ilmu Pendidikan

Universitas Muhammadiyah Palangkaraya 
I gradeical completeness is $64 \%$ with an average value of 73 , and gradeical cycle completeness is $92 \%$ with an average value of 86 .

Keywords: Direct Instruction (DI) Learning Model, Audio-Visual Media, Science Learning Outcomes.

\section{PENDAHULUAN}

Pendidikan memegang peranan yang sangat penting dan strategis dalam menciptakan kualitas sumber daya manusia. Berbagai usaha telah dilakukan untuk meningkatkan mutu pendidikan nasional, antara lain melalui pelatihan dan peningkatan kualitas guru, penyempurnaan kurikulum, pengadaan buku dan alat pelajaran, perbaikan sarana dan prasarana pendidikan, dan peningkatan mutu manajemen sekolah. Namun, berbagai indikator mutu pendidikan tersebut belum menunjukkan peningkatan yang memadai. Berlakunya Kurikulum Tingkat Satuan Pendidikan (KTSP) sekarang ini, sangat menuntut perubahan paradigma dalam pendidikan dan pengajaran, khususnya pada jenis dan jenjang pendidikan formal. Perubahan tersebut harus pula diikuti oleh guru yang bertanggung jawab atas penyelenggaraan pembelajaran di sekolah (di dalam kelas ataupun di luar kelas).

Menurut Komarudin (dalam Trianto, 2009:2) menyatakan bahwa "salah satu perubahan paradigma pembelajaran tersebut adalah orientasi pembelajaran yang semula berpusat pada guru (teacher centered) beralih berpusat pada siswa (student centered). Semua perubahan tersebut dimaksudkan untuk memperbaiki mutu pendidikan, baik dari segi proses maupun hasil pendidikan". Namun, strategi yang selama ini digunakan oleh guru dalam pembelajaran adalah metode ceramah, metode tanya jawab, metode penugasan, dan metode ekspositori sehingga guru lebih banyak mendominasi proses pembelajaran dengan memberikan informasi kepada peserta didik, tanpa memberikan peserta didik tersebut untuk mencari sendiri konsep yang akan dipelajarinya. KTSP sekarang ini, juga menghendaki bahwa suatu pembelajaran pada dasarnya tidak hanya mempelajari tentang konsep, teori, dan fakta, tetapi juga aplikasi dalam kehidupan sehari-hari. Dengan demikian, materi pembelajaran tidak hanya tersusun atas halhal sederhana yang bersifat hapalan dan pemahaman, tetapi juga tersusun atas materi yang kompleks yang memerlukan analisis, aplikasi, dan sintesis. Untuk itu, guru harus dapat menciptakan situasi dan kondisi kelas yang kondusif agar proses belajar mengajar dapat berlangsung sesuai dengan tujuan yang diharapkan.

Undang-Undang Sistem Pendidikan Nasional No. 20 Tahun 2003 Pasal 37 Ayat (1) Kurikulum pendidikan dasar dan menengah salah satunya wajib memuat ilmu pengetahuan alam. Sesuai dengan Undang-Undang tersebut, maka mata pelajaran Ilmu Pengetahuan Alam wajib diberikan pada siswa-siswa pada jenjang pendidikan dasar dan menengah. Pada jenjang pendidikan dasar dan menengah mata pelajaran IPA harus mencakup beberapa standar kompetensi dan kompetensi dasar. Standar kompetensi dan kompetensi dasar dalam mata pelajaran IPA tersebut tertuang dalam standar isi.

Peraturan Menteri Pendidikan Nasional Nomor 22 Tahun 2006 tentang standar isi untuk satuan pendidikan dasar

*Dedy Setyawan dan **Agung Riadin

Dosen Fakultas Keguruan dan Ilmu Pendidikan

Universitas Muhammadiyah Palangkaraya 
dan menengah bahwa standar kompetensi IPA merupakan standar minimum yang secara nasional harus dicapai oleh peserta didik dan menjadi acuan dalam pengembangan kurikulum di setiap satuan pendidikan. Pencapaian SK dan KD didasarkan pada pemberdayaan peserta didik untuk membangun kemampuan, bekerja ilmiah, dan pengetahuan sendiri yang difasilitasi oleh guru. Penerapan IPA perlu dilakukan secara bijaksana agar tidak berdampak buruk terhadap lingkungan. IPA diperlukan dalam kehidupan sehari-hari untuk memenuhi kebutuhan manusia melalui pemecahan masalah-masalah yang dapat diidentifikasi. Oleh karena itu pembelajaran IPA di SD/MI menekankan pada pemberian pengalaman belajar secara langsung melalui penggunaan dan pengembangan keterampilan proses dan sikap ilmiah.

Mata pelajaran IPA merupakan salah satu dari sejumlah mata pelajaran yang diajarkan di Sekolah Dasar sesuai dengan kurikulum pendidikan dasar. Ilmu Pengetahuan Alam (IPA) berkaitan dengan cara mencari tahu tentang alam secara sistematis, sehingga IPA bukan hanya penguasaan kumpulan pengetahuan yang berupa fakta-fakta, konsep-konsep atau prinsip-prinsip saja tetapi juga merupakan suatu proses penemuan. Oleh karena itu, pendidikan IPA diharapkan dapat menjadi wahana bagi peserta didik untuk mempelajari diri sendiri dan alam sekitar (Trianto, 2007).

Selama ini pembelajaran IPA di sekolah dasar masih banyak mengalami hambatan yang menjadi problematika dalam pendidikan IPA. Salah satunya adalah proses pembelajaran yang diberikan di kelas pada umumnya hanya mengemukakan konsep-konsep dalam suatu materi. Hal ini nampak pada rerata hasil belajar peserta didik yang senantiasa masih sangat memprihatinkan. Prestasi ini merupakan hasil kondisi pembelajaran yang masih bersifat konvensional dan tidak menyentuh ranah siswa itu sendiri, yaitu bagaimana sebenarnya belajar itu. Dengan kata lain, bahwa proses pembelajaran masih memberikan dominasi guru dan tidak memberikan akses bagi siswa untuk berkembang secara mandiri melalui penemuan dan proses berpikirnya. Kondisi seperti itu tidak akan meningkatkan kemampuan siswa dalam memahami pelajaran IPA. Memperhatikan permasalahan di atas sudah selayaknya seorang guru dalam pembelajaran IPA melakukan sebuah inovasi untuk meningkatkan kualitas mutu pendidikan yang secara khusus memerlukan perubahan pola pikir positif yang digunakan sebagai landasan pelaksanaan kurikulum.

\section{Belajar}

Menurut Susanto, (2013:3) belajar dapat diartikan sebagai perubahan tingkah laku pada diri indVidu berkat adanya interaksi antara indVidu dengan indVidu lain dan indVidu dengan lingkungannya sehingga mereka lebih mampu berinteraksi dengan lingkungannya". Tujuan belajar adalah sejumlah hasil belajar yang menunjukan bahwa siswa telah melakukan tugas belajar, yang umumnya meliputi pengetahuan, keterampiln dan sikap-sikap yang baru, yang diharapkan tercapai oleh siswa. hasil belajar merupakan perubahanperubahan yang terjadi pada diri siswa yang menyangkut tiga kriteria yaitu aspek kognitif, afektif dan psikomotor sebagai hasil dari kegiatan belajar.

*Dedy Setyawan dan **Agung Riadin 


\section{Ilmu Pengetahuan Alam (IPA)}

Ilmu Pengetahuan Alam (IPA) adalah cara mencari tahu tentang alam secara sistematis untuk menguasai pengetahuan, fakta-fakta, konsep-konsep, prinsip-prinsip, proses penemuan dan memiliki sikap ilmiah. (Depdiknas, 2004 : 32). Mata pelajaran IPA di Sekolah Dasar (SD) berfungsi untuk menguasai konsep dan manfaat IPA dalam kehidupan sehari-hari serta untuk melanjutkan pendidikan menengah pertama serta bertujuan :

1) Menanamkan pengetahuan dan konsep-konsep sains yang bermanfaat dalam kehidupan sehari-hari.

2) Menanamkan rasa ingin tahu, dan sikap positif terhadap IPA

3) Mengembangkan keterampilan proses untuk menyelidiki alam sekitar, memecahkan masalah dan membuat keputusan.

4) Mengembangkan kesadaran tentang adanya hubungan yang saling mempengaruhi antara IPA, lingkungan teknologi dan masyarakat.

5) Mengembangkan kesadaran tentang adanya hubungan yang saling mempengaruhi IPA.

6) Ikut serta dalam memelihara, menjaga, dan melestarikan lingkungan alam.

7) Menghargai alam dan segala keteraturan sebagai salah satu ciptaan Tuhan.

\section{Model Direct Instraction (DI)}

Pembelajaran langsung (Direct Instruction) sering disebut juga dengan metode ekspositori karena sifatnya samasama memberi informasi. Namun dalam pelaksanaan metode ekspositori peran dominasi guru banyak dikurangi, guru hanya memberi informasi kepada bagian atau saat-saat yang diperlukan. Misalnya pada awal pembelajaran guru, pada topik baru, pada waktu memberikan contohcontoh soal, selanjutnya peserta didik diminta menyelesaikan soal-soal di papan tulis atau di meja masing-masing. Dalam praktiknya Direct Instruction sangat bergantung pada kemampuan guru mengelola pembelajaran. Pengajaran ini relevan bagi guru yang ingin mengajar eksprimen atau percobaan. Pembelajaran ini berpusat pada guru, tetapi tetap menjamin terjadinya keterlibatan siswa, jadi lingkungan belajarnya harus diciptakan yang berorientasi pada tugas-tugas yang harus diberikan kepada siswa. Model Direct Instruction secara khusus dirancang untuk mempromosikan belajar siswa dengan pengetahuan prosedural dan pengetahuan deklaratif yang terstruktur dengan baik dan dapat diajarkan secara langkah-demilangkah.

Trianto (2009:41-42) menyebutkan ciri-ciri pembelajaran langsung sebagai berikut:(a) adanya tujuan pembelajaran;(b) ada sintaksis atau pola keseluruhan dan alur kegiatan pembelajaran;(c) sistem pengelolaan dan lingkungan belajar yang mendukung pembelajaran.

Adapun kelebihan model Direct Instruction yaitu dirancang secara spesifik untuk meningkatkan pengetahuan faktual yang diajarkan secara tahap demi tahap dengan tujuan untuk membantu peserta didik menguasai pengetahuan prosedural yang dibutuhkan untuk melakukan berbagai keterampilan kompleks. Salah satu tahapan dari model Diresct Instruction adalah demonstrasi. Selama pembelajaran berlangsung peserta didik dapat mengamati, memperhatikan dan melaksanakan sendiri

*Dedy Setyawan dan **Agung Riadin

Dosen Fakultas Keguruan dan Ilmu Pendidikan

Universitas Muhammadiyah Palangkaraya 
apa yang didemonstrasikan guru sehingga pemahaman materi yang demikian akan lebih mendalam dan berkesan bagi peserta didik karena peserta didik ikut mengalami sendiri.

Kelemahan model Direct Intruction yaitu dalam model ini berpusat pada guru, maka kesuksesan pembelajaran bergantung pada guru. Jika guru kurang dalam persiapan, pengetahuan, kepercayaan diri, antusiasme maka siswa dapat menjadi bosan, teralihkan perhatiannya, dan pembelajaran akan terhambat. Jika terlalu sering menggunakan model Direct Intruction akan membuat beranggapan bahwa guru akan memberitahu siswa semua informasi yang perlu diketahui. Untuk mengantisipasi kekurangan yang ada dalam model Direct Intruction. Karena dalam model Direct Intruction adalah pembelajaran yang berpusat pada guru. Maka dalam persiapan untuk mengajar dipersiapkan dengan matang dan sebaik mungkin jangan sampai ada kekurangan sedikitpun. Guru harus berkomunikasi dengan baik pada peserta didik agar peserta didik merasa antusias dalam mengikuti pembelajaran. Dalam penyampaian materi juga harus terperinci atau bertahap agar siswa tidak kebingungan terhadap materi yang diajarkan.

\section{Media Pembelajaran Audio Visual}

Media pembelajaran adalah segala sesuatu yang dapat digunakan untuk menyampaikan pesan dan dapat merangsang perhatian, minat, pikiran, dan perasaan peserta didik dalam kegiatan pembelajaran untuk mencapai tujuan pembelajaran tertentu.

Manfaat media pembelajaran adalah dapat membuat suatu pembelajaran menjadi lebih menarik dan lebih jelas serta metode mengajar akan lebih bervariasi seperti mengamati, melakukan, mendemonstrasikan aktivitas peserta didik dalam menunjang proses pembelajaran.

Jenis media pembelajaran ada 4 jenis yaitu media grafis, media tiga dimensi, media proyeksi dan media penggunaan lingkungan sebagai media pembelajaran dengan memanfaatkan sarana dan prasarana yang ada.

Media Audio adalah alat media yang isi pesannya hanya diterima melalui indera pendengaran saja. Media audio yang dimaksud disini adalah suara-suara ataupun bunyi yang berkaitan dengan materi pembelajaran direkam dengan menggunakan alat perekam suara, kemudian hasil perekaman tersebut diperdengarkan kembali kepada peserta didik dengan menggunakan sebuah alat pemutarnya. Media audio visual adalah media kombinasi antara audio dan visual yang dikombinasikan dengan kaset audio yang mempunyai unsur suara dan gambar yang biasa dilihat, misalnya rekaman video, berbagai ukuran film, slide suara dan sebagainya.

Media audio visual ini dapat dibagi menjadi dua jenis. Jenis pertama, dilengkapi fungsi perlatan suara dan gambar dalam satu unit, dinamakan media audio-visual murni, sepert film gerak (movie) bersuara, televisi dan video. Jenis kedua adalah media audio visual tidak murni yakni apa yang kita kenal dengan slide, opaque, OHP, dan peralatan visual lainnya bila diberi unsur suara dari rekaman kaset yang dimanfaatkan secara bersamaan dalam satu waktu atau satu proses pembelajaran. Tetapi demikian itu tidak mengubah hakikatnya sebagai peralatan

*Dedy Setyawan dan **Agung Riadin

Dosen Fakultas Keguruan dan Ilmu Pendidikan

Universitas Muhammadiyah Palangkaraya 
media audio visual. Karena unsur gambar pada jenis kedua ini berupa gambar yang diproyeksikan, maka tayangan gambar tersebut tetap gambar dian (still picture), tidak bergerak dan termasuk media visual.

Teknologi Audio visual cara untuk menghasilkan atau menyampaikan materi yaitu dengan menggunakan mesin-mesin mekanis dan elektronik untuk menyajikan pesan-pesan audio dan visual. Pengajaran melalui audio-visual jelas bercirikan pemakaian perangakat keras selama proses belajar, seperti mesin proyektor film, tape recorder, dan proyektor visual yang lebar.

Secara umum, media audio-visual memiliki kelebihan dan keterbatasan. Kelebihannya: fleksibel, relative murah, ringkas, mudah dibawa (portable). Kelemahannya: memerlukan peralatan khusus, memerlukan kemampuan/ ketrampilan khusus untuk pemanfaatannya.

\section{METODE PENELITIAN}

Metode penelitian yang digunakan ini adalah Penelitian Tindakan Kelas (PTK), karena penelitian ini merupakan suatu pencermatan terhadap kegiatan berupa sebuah tindakan kelas, yang sengaja dimunculkan dan terjadi di dalam sebuah kelas.

Berdasarkan pendapat di atas, dapat disimpulkan penelitian tindakan kelas atau PTK adalah suatu peranan yang sangat penting dan strategis untuk meningkatkan mutu di berbagai aspek pembelajaran. Pada penelitian tindakan kelas ini peneliti berperan sebagai guru untuk mengajar mata pelajaran IPA. Subjek penelitian ini yaitu peserta didik kelas V SDN-1 Langkai Palangkaraya dengan rincian sebagai berikut:
Tabel 1.

Subjek Penelitian

\begin{tabular}{|l|l|l|l|}
\hline Kelas & $\begin{array}{l}\text { Laki- } \\
\text { laki }\end{array}$ & Perempuan & Jumlah \\
\hline $\mathrm{V}$ & 13 & 12 & 25 \\
\hline
\end{tabular}

Sumber : Absensi kelas V SDN-1 Langkai Palangkaraya

Penelitian ini menggunakan rancangan PTK yang dicirkan dengan adanya siklus-siklus, setiap siklus terdiri dari empat tahapan yaitu "perencanaan, pelaksanaan tindakan, observasi dan refleksi/evaluasi".Alur pelaksanaan penelitian tindakan kelas menurut Kemmis dan McTaggart (dalam Suhardjono dkk, 2010:75) untuk lebih jelasnya dapat dilihat pada bagan berikut:

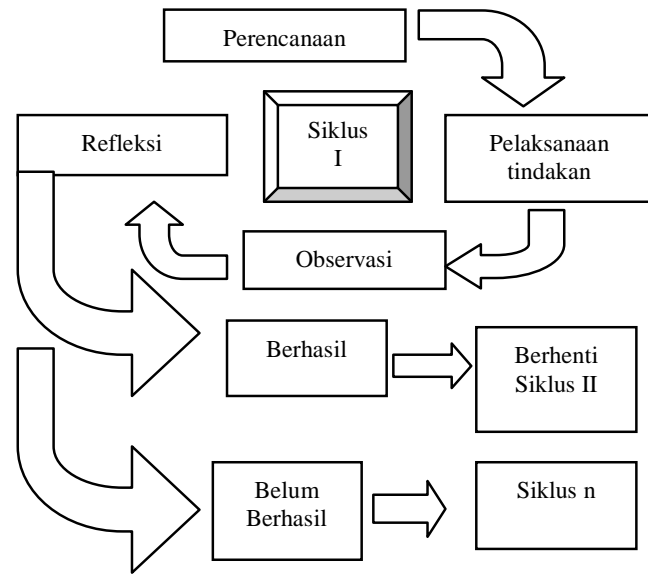

Gambar 1.

Bagan Siklus Penelitian Tindakan Kelas (PTK)

Sumber : Kemmis dan Mc Taggart (dalam Suhardjono, 2010:75)

Teknik dan pengumpulan data yang digunkan dalam penelitian ini adalah tes dan observasi, penelitian ini akan menggunakan data kualitatif dan data kuantitatif. Validitas instrumen tes dilakukan untuk mengetahui apakah instrumen dapat mengukur apa yang

*Dedy Setyawan dan **Agung Riadin 
seharus nya di ukur. Validitas instrumen ditentukan melalui pendapat para ahli tentang isi materi tes, para ahli yang memutuskan valid atau tidaknya isi tes yaitu dengan meminta bantuan dari dua orang dosen ahli.

\section{HASIL PENELITIAN DAN} PEMBAHASAN

1. Aktivitas belajar peserta didik menjadi baik dengan menggunakan model pembelajaran Direct Instraction (DI) berbantuan media Audio Visual dalam pembelajaran IPA pada peserta didik kelas V SDN1 Langkai Palangka Raya, terlihat dari aktivitas guru pada siklus I ratarata 2,3 kategori cukup baik dan siklus II rata-rata 3,5 kategori baik, sedangkan aktivitas peserta didik siklus I rata-rata 2,5 kategori cukup dan siklus II rata-rata 3,5 kategori baik. Pada aktivitas belajar peserta didik setelah menggunakan model pembelajaran yang berbantuan media Audio Visual membuat aktif proses pembelajaran. Peserta didik terlihat fokus mendengarkan guru menjelaskan materi pembelajaran berbantuan video tentang kenampakan benda-benda langit.

Berikut ini adalah grafik yang menunjukkan persentase aktivitas guru dan peserta didik selama proses pembelajaran IPA pada saat pelaksanaan tindakan siklus I dan siklus II.

Tabel 17

Aktivitas Guru dan Peserta Didik selama Proses Pembelajaran IPA

\begin{tabular}{|l|l|l|}
\hline No. & Aktivitas & Skor \\
\hline
\end{tabular}

\begin{tabular}{|l|l|l|l|}
\hline & & Siklus I & \multicolumn{1}{|c|}{ Siklus II } \\
\hline 1. & $\begin{array}{l}\text { Aktivitas } \\
\text { Guru }\end{array}$ & 2,3 & 3,5 \\
\hline 2. & $\begin{array}{l}\text { Aktivitas } \\
\text { Peserta } \\
\text { Didik }\end{array}$ & 2,5 & 3,5 \\
\hline
\end{tabular}

Adapun grafik aktivitas guru dan peserta didik digambarkan sebagai berikut:

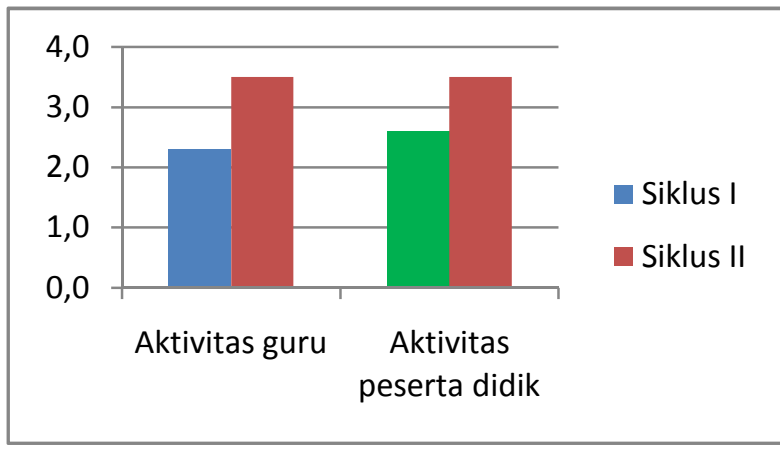

\section{Grafik 1.}

Aktivitas Guru dan Peserta Didik dalam

Proses Pembelajaran IPA

Siklus I dan Siklus II

2. Terdapat peningkatan hasil belajar IPA menggunakan model pembelajaran Direct Instraction (DI) berbantuan media Audio Visual pada peserta didik kelas V SDN-1 Langkai Palangka Raya . Berdasarkan hasil analisis peneliti diperoleh data bahwa pada Pra tindakan ketuntasan klasikal yaitu $52 \%$ dengan nilai rata-rata 65 , sedangkan di siklus I ketuntasan klasikal yaitu $64 \%$ dengan nilai ratarata 73 dan ketuntasan klasikal di Siklus II diperoleh data ketuntasan belajar peserta didik secara klasikal siklus II yaitu $92 \%$ dengan nilai ratarata 86 . Hasil belajar IPA pada materi kenampakan benda-benda langit dengan menggunakan model Direct

*Dedy Setyawan dan **Agung Riadin

Dosen Fakultas Keguruan dan Ilmu Pendidikan

Universitas Muhammadiyah Palangkaraya 
Instraction (DI) berbantuan media audio visual terbukti meningkatkan hasil belajar IPA. Peserta didik lebih mudah memahami materi, memberi motivasi belajar, dan pembelajaran menjadi lebih menyenangkan.

Ketuntasan hasil belajar IPA pada pra tindakan, siklus I, siklus II dapat disajikan pada grafik di bawah ini :

Tabel 18

Hasil Belajar IPA Peserta Didik

\begin{tabular}{|l|l|l|l|l|}
\hline $\begin{array}{l}\text { N } \\
\text { o. }\end{array}$ & Data & $\begin{array}{l}\text { Skor } \\
\text { Rata } \\
\text {-rata }\end{array}$ & $\begin{array}{l}\text { Skor } \\
\text { Maksi } \\
\text { mal }\end{array}$ & $\begin{array}{l}\text { Persentase } \\
\text { Ketuntasan } \\
\text { Klasikal }\end{array}$ \\
\hline 1. & $\begin{array}{l}\text { Pra } \\
\text { Tindakan }\end{array}$ & 65 & 100 & $52 \%$ \\
\hline 2. & Siklus I & 73 & 100 & $64 \%$ \\
\hline 3. & Siklus II & 86 & 100 & $92 \%$ \\
\hline
\end{tabular}

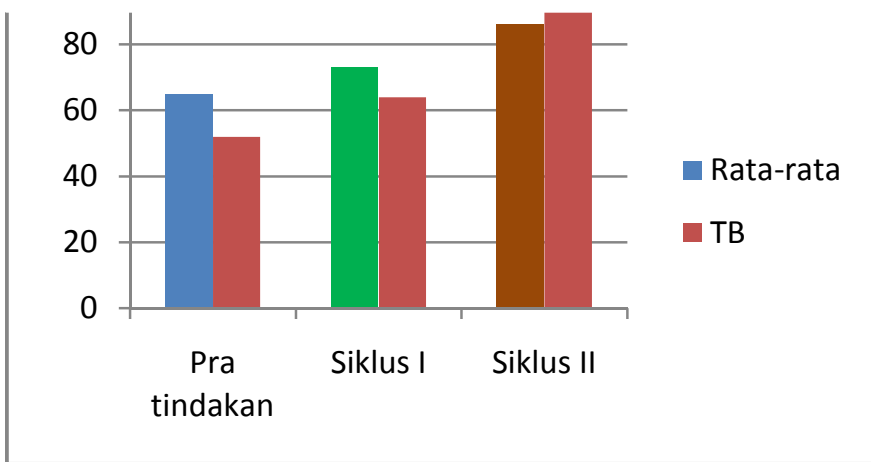

Grafik2.

Ketuntasan Hasil Belajar IPA

Pra Tindakan, Siklus I, Siklus II

\section{KESIMPULAN}

Dari hasil penelitian dan pembahasan, maka dapat diambil kesimpulan sebagai berikut:
1. Aktivitas belajar peserta didik menjadi baik dengan menggunakan model pembelajaran Direct Instraction (DI) berbantuan media Audio Visual dalam pembelajaran

2. IPA pada peserta didik kelas VSDN-1 Langkai Palangka Raya, terlihat aktivitas guru pada siklus I rata-rata 2,3 kategori cukup baik dan siklus II rata-rata 3,5 kategori baik, sedangkan aktivitas peserta didik siklus I ratarata 2,5 kategori cukup dan siklus II rata-rata 3,5 kategori baik.

3. Terdapat peningkatan hasil belajar IPA menggunakan model pembelajaran Direct Instraction (DI) berbantuan media Audio Visual pada peserta didik kelas V SDN-1 Langkai Palangka Raya dengan hasil analisis pada Pra tindakan ketuntasan klasikal yaitu 52\% dengan nilai rata-rata 65 siklus I ketuntasan klasikal yaitu $64 \%$ dengan nilai rata-rata 73 , dan ketuntasan klasikal siklus II $92 \%$ dengan nilai rata-rata 86.

Untuk meningkatkan hasil belajar IPA pada peserta didik, maka peneliti memberikan rekomendasi sebagai berikut:

1. Peserta Didik, diharapkan meningkatkan aktivitas belajar peserta didik dalam proses pembelajaran melalui kerja sama antar peserta didik dalam menemukan konsep-konsep IPA.

2. Guru, diharapkan menggunakan model pembelajaran Direct Instraction (DI) untuk mata pelajaran lain.

3. Sekolah, diharapkan menyediakan sarana dan prasarana pembelajaran yang dapat menunjang aktivitas belajar.

*Dedy Setyawan dan **Agung Riadin 


\section{DAFTAR PUSTAKA}

Depdiknas. 2004. Perpustakaan Perguruan Tinggi: Buku Pedoman, edisi ketiga. Jakarta: Depdiknas.

Diplan \& Rini. 2019. Analisis Kesulitan Belajar Dalam Materi Menanggapi Suatu Cerita Pada Mata Pelajaran Bahasa Indonesia Kelas III Di SD Muhammadiyah. Neraca: Jurnal Pendidikan Ekonomi, 5(1):32-36.

Jakarta : Prestasi

Mulyasa, E. 2011. Standar Kompetensi dan Sertifikasi Guru. Bandung : Rosda.

Putra, Chandra Anugrah. 2017. Pemanfaatan Teknologi Gadget Sebagai Media Pembelajaran. Bitnet : Jurnal Pendidikan Teknologi Informasi, 2(2):1-10.

Ramli, Muhamad \& Isnawati. 2016. Upaya Meningkatkan Hasil Belajar IPS dengan Menggunakan Model Pembelajaran Course Review Horay. Bitnet: Jurnal Pendidikan Teknologi Informasi, 1(1):6-10.

Setiawan, M Andi \& Diplan. 2018. Penelitian Tindakan Kelas. Yogyakarta: DEEPUBLISH.

Setiawan, M. Andi. 2017. Belajar dan Pembelajaran. Uwais Inspirasi Indonesia.

Sudjana dan Rivai. 2002. Media Pendidikan. Jakarta: Balai Pustaka.

Suhardjono, Supardi. 2011. Penelitian TindakanKelas. Jakarta: Bumi. Aksara.

Susanto. Ahmad, 2013. Teori Belajar dan Pembelajaran di SekolahDasar. Jakarta: Kencana Prenadamedia Group

Trianto. 2009. Model-model Pembelajaran Inovatif Berorientasi Konstruktivistik.

*Dedy Setyawan dan **Agung Riadin 